\title{
Pengaruh Perbandingan Tepung Ubi Jalar Ungu Dan Tepung Kedelai Terhadap Karakteristik Flakes Sebagai Pangan Fungsional
}

\section{The Effect Of Ratio Purple Sweet Potato Flour And Soybean Flour On Characteristics Flakes As Functional Food}

\author{
Ratna Mei Rani ${ }^{1}$, I Gusti Ayu Ekawati ${ }^{1 *}$, A.A.I. Sri Wiadnyani ${ }^{1}$ \\ Program Studi Teknologi Pangan, Fakultas Teknologi Pertanian, \\ Universitas Udayana, Kampus Bukit Jimbaran, Badung-Bali \\ Penulis korespondensi: IG.A.Ekawati, Email: ayuekawati@unud.ac.id
}

\begin{abstract}
The research aim to determine the effect of ratio purple sweet potato flour and soybean flour on characteristics functional flakes and determine the exact ratio of purple sweet potato flour and soybean flour which can produce functional flakes with the best characteristics. The Completed Randomized Design was used in this research consisting ratio of purple sweet potato flour and soybean flour including (P1) $90 \%: 10 \%$, (P2) $80 \%: 20 \%$, (P3) 70\%: 30\%, (P4) 60\%: 40\%, (P5) 50\%: 50\%. The data obtained were analyzed by variance and if the treatment had significant effect followed by Duncan Multiple Range Test (DMRT). The result showed that flakes with comparison of 70\% purple sweet potato flour and 30\% soybean flour is the best treatments with criteria moisture content of $3.05 \%$, ash content of $2.09 \%$, protein content of $17.04 \%$, crude fiber $3.76 \%$, anthocyanin total $21.07 \mathrm{mg} / 100 \mathrm{~g}$, antioxidant activity $39.55 \%$, water absorption $165.66 \%$ and color is purple and like, aroma is like, texture is crispy and like, taste is like and overall acceptance is like.
\end{abstract}

Keywords : Flakes, Purple sweet potato flour, Soybean flour, Funtional Food

\section{PENDAHULUAN}

Flakes adalah makanan sarapan siap santap yang biasanya dibuat dari bahan pangan serealia diantaranya jagung, beras, barley, gandum dan olahannya seperti terigu. Flakes pada umumnya memiliki karakteristik berbentuk remahan, pipih atau serpihan dan memiliki kemampuan rehidrasi (Gupta, 1990). Secara umum, tahapan proses pengolahan flakes adalah persiapan bahan baku, pembentukan adonan, pemasakan, dan pengemasan. Salah satu upaya untuk diversifikasi bahan baku dalam pembuatan flakes adalah dengan menggunakan bahan pangan lokal seperti ubi jalar ungu, dimana ubi jalar ungu memiliki kandungan karbohidrat yang cukup tinggi sehingga dapat dimanfaatkan sebagai bahan baku pembuat flakes.

Pangan fungsional menurut Badan Pengawas Obat dan Makanan (BPOM) adalah pangan yang secara alamiah maupun telah melalui proses, mengandung satu atau lebih senyawa yang mempunyai fungsi fisiologis tertentu yang bermanfaat bagi kesehatan (Herlina et al., 2014). Ubi jalar ungu dapat 
digunakan sebagai bahan baku pangan fungsional, karena mengandung senyawa yang dapat bekerja sebagai antioksidan, salah satu senyawa antioksidan yang terkandung dalam ubi jalar ungu adalah antosianin, selain itu ubi jalar ungu kaya akan serat yang dibutuhkan oleh tubuh. Antosianin merupakan senyawa flavonoid yang didapatkan dari pigmen berwarna ungu yang menyebar dari bagian kulit sampai pada daging ubinya (Santoso, 2014). Kandungan antosianin yang terdapat pada ubi jalar ungu berpotensi sebagai pangan fungsional karena dapat memberikan efek fisiologis bagi tubuh, yaitu berperan untuk mencegah terjadinya penuaan, kanker, dan penyakit degeneratif, selain itu antosianin juga memiliki kemampuan sebagai antimutagenik dan antikarsinogenik, mencegah gangguan fungsi hati, antihipertensi, dan menurunkan kadar gula darah (Jusuf et al., 2008). Kandungan antosianin dari ubi jalar ungu berkisar antara $110 \mathrm{mg} / 100 \mathrm{~g}$ sampai 210 mg/100 g bahan (Suprapta, 2004). Ubi jalar ungu mengandung serat 3,04 \% /100 g bahan (Heriyanto et al., 1999).

Kelemahan ubi jalar ungu yaitu memiliki kandungan protein yang relatif rendah yang hanya mengandung sebanyak $1,80 \mathrm{~g} / 100 \mathrm{~g}$ bahan (Anon, 1981). Untuk menunjang zat gizi flakes yang berbahan baku dari ubi jalar ungu maka dilakukan penambahan kedelai sebagai sumber protein. Kedelai merupakan salah satu sumber protein nabati yang mempunyai mutu atau nilai biologi tertinggi. Kandungan protein yang terkandung dalam kedelai masing-masing dapat mencapai 35-54\% dan lebih tinggi jika dibandingkan dengan jenis kacang-kacangan lainnya (Somaatmadja, 1993).

Berdasarkan uraian di atas, maka penelitian ini dilakukan untuk mengetahui pengaruh perbandingan tepung ubi jalar ungu dan tepung kedelai terhadap karakteristik flakes fungsional serta menentukan perbandingan yang tepat dari tepung ubi jalar ungu dan tepung kedelai yang dapat menghasilkan flakes fungsional dengan karakteristik terbaik. Melalui penggunaan bahan baku ubi jalar ungu dan kedelai yang berasal dari bahan pangan lokal diharapkan dapat meningkatkan nilai gizi dan fungsional pada produk flakes, sehingga dapat dijadikan sebagai produk pangan fungsional.

\section{METODE PENELITIAN}

\section{Tempat dan Waktu}

Penelitian ini dilakukan di Laboratorium Pengolahan Pangan, Laboratorium Analisis Pangan serta Laboratorium Pasca Panen Fakultas Teknologi Pertanian Universitas Udayana. Penelitian ini dilakukan pada bulan Januari Februari 2020.

\section{Bahan dan Alat}

Bahan yang digunakan dalam penelitian ini adalah ubi jalar ungu varietas ayamurasaki, 
kedelai (bola biru), tapioka (rose brand), gula halus (claris), garam (cap kapal), margarin(blue band) dan air (aqua) yang diperoleh dari toko kurnia Jimbaran. Bahan kimia yang digunakan adalah alkohol, aquades, tablet Kjeldahl, methanol PA, indikator PP (penolphtalin), $\mathrm{H}_{2} \mathrm{SO}_{4}$ (Merck), $\mathrm{NaOH}$ (Merck), $\mathrm{HCl}$ (Merck), $\mathrm{H}_{3} \mathrm{BO}_{3}$ (Merck), larutan buffer PH 1 (Merck), larutan buffer PH 4,5 (Merck) dan 2,2-diphenyl-1picrylhidrazyl (DPPH).

Alat-alat yang digunakan dalam penelitian ini adalah baskom, pisau, sendok, blender, loyang oven, aluminium foil, dandang, kompor, ayakan 60 mesh, tabung reaksi, gelas ukur, gelas beaker, kertas saring, corong, pipet tetes, vortex, cawan, buret, desikator, kertas whattman, muffle, labu kjeldahl, corong kaca, pemanas listrik, tanur, labu takar, pompa karet, destilator dan labu erlenmeyer, oven (Labo DO 225), timbangan analitik (Shimadzu ATY224), spektofotometer (Genesys 10S UV-Vis).

\section{Rancangan Percobaan}

Penelitian dilakukan dengan menggunakan Rancangan Acak Lengkap (RAL) dengan perlakuan 5 taraf dan 3 kali ulangan pada masing-masing perlakuan sehingga diperoleh 15 unit percobaan. Perlakuan perbandingan tepung ubi jalar ungu dan tepung kedelai terdiri dari 5 taraf yaitu : $\mathrm{P} 1=90 \%$ (tepung ubi jalar ungu) $: 10 \%$ (tepung kedelai) $; \mathrm{P} 2=80 \%$ (tepung ubi jalar ungu) : 20\% (tepung kedelai) ; P3 $=70 \%$ (tepung ubi jalar ungu) : 30\% (tepung kedelai) ; $\mathrm{P} 4=60 \%$ (tepung ubi jalar ungu) : 40\% (tepung kedelai) $;$ P5 $=50 \%$ (tepung ubi jalar ungu) : 50\% (tepung kedelai). Data yang diperoleh dianalisis dengan sidik ragam dan apabila perlakuan berpengaruh terhadap variabel yang diamati maka dilanjutkan dengan uji Duncan's Multiple Range Test (DMRT) (Gomez dan Gomez, 1995).

\section{Parameter yang Diamati}

Parameter yang diamati pada penelitian ini meliputi analisis kadar air dengan metode pengeringan, kadar abu metode pengabuan, kadar protein metode Mikro Kjeldahl, kadar serat kasar yang dilakukan dengan metode hidrolisis asam basa (Sudarmadji et al., 1997), analisis total antosianin dengan metode $\mathrm{pH}$ Differensial (Cheng et al., 1991), analisis aktivitas antioksidan dengan metode 2,2diphenyl-1-picrylhidrazyl (DPPH) (Khan et al., 2012), uji daya serap air flakes dilakukan berdasarkan metode gravimetri (Dewi, 2008), serta evaluasi sensoris yang meliputi warna, aroma, tekstur, rasa dan penilaian keseluruhan menggunakan uji hedonik dan uji skoring untuk warna dan tekstur dengan metode yang dilakukan oleh (Soekarto, 1985).

\section{Pelaksanaan Peneltian}

\section{Proses Pembuatan Tepung Ubi Jalar Ungu}

Proses pembuatan tepung ubi jalar ungu mengacu pada penelitian (Ekawati et al., 2013). Tahapan pertama dalam pembuatan 
tepung ubi jalar ungu adalah sortasi dengan memilih ubi jalar ungu dengan kualitas yang baik (tidak rusak, tidak banyak lekukan dan tidak busuk), selanjutnya dibersihkan dari kotoran. Ubi jalar ungu dicuci pada air yang mengalir dan dikupas kulitnya, kemudian ubi jalar ungu diiris tipis. Hasil dari irisan tersebut dimasukkan ke dalam loyang yang telah dilapisi dengan aluminium foil dan diratakan, kemudian dikeringkan dalam oven selama 4 jam pada suhu $60^{\circ} \mathrm{C}$. Ubi jalar ungu yang sudah kering kemudian dihaluskan dengan blender dan kemudian diayak dengan ayakan 60 mesh sehingga diperoleh tepung ubi jalar ungu.

\section{Proses Pembuatan Tepung Kedelai}

Proses pembuatan tepung kedelai mengacu pada penelitian (Nurali et al., 2010) yang dimodifikasi. Tahapan pertama dalam pembuatan tepung kedelai adalah sortasi dengan cara memilih kedelai yang mutunya baik (tidak rusak dan bebas dari cemaran), selanjutnya dibersihkan dengan cara dicuci dengan air mengalir dan direndam selama 30 menit. Setelah direndam kemudian ditiriskan dan direbus selama 15 menit, kemudian dihilangkan kulit arinya lalu dikeringkan ke dalam oven selama 20 jam pada suhu $60{ }^{\circ} \mathrm{C}$. Kedelai yang sudah kering kemudian dihaluskan dengan blender dan kemudian diayak dengan ayakan 60 mesh sehingga diperoleh tepung kedelai.

\section{Proses Pembuatan Flakes}

Proses pembuatan flakes mengacu pada penelitian (Permana et al., 2015) yang dimodifikasi. Tahapan pertama dalam proses pembuatan flakes adalah dengan mencampurkan semua bahan tepung ubi jalar ungu, tepung kedelai, tapioka, garam dan gula halus sesuai perlakuan. Ditambahkan air dan dilakukan pengadukan sampai kalis hingga terbentuk adonan, kemudian dilakukan pengukusan adonan selama 15 menit pada suhu $100{ }^{0} \mathrm{C}$. Adonan yang telah dikukus kemudian dibentuk menjadi lembaran dengan menggunakan kayu penggiling adonan hingga mencapai ketebalan $\pm 1 \mathrm{~mm}$. Kemudian dilakukan pengovenan selama \pm 10 menit pada suhu $160{ }^{\circ} \mathrm{C}$ dan didapatkan lembaran flakes, selanjutnya flakes yang sudah jadi dalam bentuk lembaran diremukkan sampai berbentuk remahan-remahan kecil.

\section{HASIL DAN PEMBAHASAN}

\section{Analisis Flakes}

Nilai rata-rata kadar air, kadar abu, kadar protein dan kadar serat kasar flakes fungsional dapat dilihat pada Tabel 1. Nilai rata-rata total antosianin, aktivitas antioksidan dan daya serap air flakes fungsional dapat dilihat pada Tabel 2.

\section{Kadar Air}

Hasil sidik ragam menunjukkan bahwa perbandingan tepung ubi jalar ungu dan tepung kedelai berpengaruh nyata $(\mathrm{P}<0,05)$ 
terhadap kadar air flakes. Tabel 1 menunjukkan kadar air flakes berkisar antara $2,50 \%$ sampai dengan 3,94\%. Kadar air tertinggi pada flakes diperoleh dari perlakuan P1 yaitu 3,94\%, sedangkan kadar air terendah pada flakes diperoleh dari perlakuan P5 yaitu $2,50 \%$.

Penurunan kadar air terjadi seiring dengan meningkatnya penambahan tepung kedelai, hal ini disebabkan karena kadar air tepung kedelai lebih rendah dibandingkan tepung ubi jalar ungu. Utami et al., (2018) menyatakan bahwa setiap $100 \mathrm{~g}$ tepung ubi jalar ungu mengandung 7,03\% air sedangkan tepung kedelai mengandung $6,08 \%$ air.
Santosa et al., (1998) menyatakan bahwa tingginya kandungan air pada flakes disebabkan oleh adanya pati yang telah tergelatinisasi pada proses pembuatan tepung, gelatinisasi meningkatkan daya serap air karena terputusnya ikatan hidrogen antarmolekul pati sehingga air lebih mudah masuk ke dalam molekul pati, hal inilah yang menyebabkan kadar air pada flakes semakin tinggi. Nilai kadar air maksimal yang sesuai menurut SNI : 01-4270-1996 adalah 3\% b/b (Anon, 2007). Hal ini menunjukkan bahwa pada perlakuan P3, P4 dan P5 masih memenuhi syarat mutu flakes SNI.

Tabel 1. Nilai rata-rata kadar air, kadar abu, kadar protein dan kadar serat kasar flakes fungsional

\begin{tabular}{ccccc}
\hline Perlakuan & Kadar Air (\%) & Kadar Abu (\%) & Kadar Protein (\%) & $\begin{array}{c}\text { Kadar Serat } \\
\text { Kasar }(\%)\end{array}$ \\
\hline P1 & $3,94 \pm 0,05^{\mathrm{a}}$ & $1,44 \pm 0,03^{\mathrm{d}}$ & $11,82 \pm 0,32^{\mathrm{d}}$ & $3,46 \pm 0,03^{\mathrm{d}}$ \\
P2 & $3,66 \pm 0,13^{\mathrm{b}}$ & $1,81 \pm 0,03^{\mathrm{c}}$ & $15,29 \pm 0,71^{\mathrm{c}}$ & $3,58 \pm 0,00^{\mathrm{cd}}$ \\
P3 & $3,05 \pm 0,11^{\mathrm{c}}$ & $2,09 \pm 0,05^{\mathrm{bc}}$ & $17,04 \pm 0,85^{\mathrm{b}}$ & $3,76 \pm 0,19^{\mathrm{c}}$ \\
P4 & $2,90 \pm 0,02^{\mathrm{c}}$ & $2,38 \pm 0,07^{\mathrm{ab}}$ & $17,77 \pm 0,65^{\mathrm{b}}$ & $4,36 \pm 0,19^{\mathrm{b}}$ \\
P5 & $2,50 \pm 0,08^{\mathrm{d}}$ & $2,48 \pm 0,38^{\mathrm{a}}$ & $19,68 \pm 0,34^{\mathrm{a}}$ & $5,20 \pm 0,10^{\mathrm{a}}$ \\
\hline
\end{tabular}

Keterangan: Nilai rata - rata yang diikuti oleh huruf yang berbeda pada kolom yang sama menunjukkan perlakuan yang berbeda nyata $(\mathrm{P}<0,05)$.

\section{Kadar Abu}

Hasil sidik ragam menunjukkan bahwa perbandingan tepung ubi jalar ungu dan tepung kedelai berpengaruh nyata $(\mathrm{P}<0,05)$ terhadap kadar abu flakes. Tabel 1 menunjukkan kadar abu flakes berkisar antara $1,44 \%$ sampai dengan 2,48\%. Kadar abu tertinggi pada flakes diperoleh dari perlakuan P5 yaitu 2,48\% yang berbeda tidak nyata dengan P4, sedangkan kadar abu terendah pada flakes diperoleh dari perlakuan P1 yaitu $1,44 \%$.

Peningkatan kadar abu terjadi seiring dengan meningkatnya penambahan tepung kedelai, hal ini disebabkan karena zat-zat anorganik pada tepung kedelai lebih banyak dibandingkan tepung ubi jalar ungu. Utami et al., (2018) menyatakan bahwa setiap $100 \mathrm{~g}$ 
tepung ubi jalar ungu mengandung $1,10 \%$ abu sedangkan tepung kedelai mengandung 2,60\% abu. Kadar abu yang dihasilkan berhubungan dengan mineral suatu bahan. Komponen mineral seperti zat Besi, Kalsium dan Fosfor banyak terdapat pada serealia dan kacangkacangan yang berfungsi baik dalam tubuh (winarno, 2002). Nilai kadar abu maksimal yang sesuai menurut SNI : 01-4270-1996 adalah 4\% b/b (Anon, 2007). Hal ini menunjukkan bahwa kadar abu yang dihasilkan pada semua perlakuan telah memenuhi syarat mutu flakes SNI.

\section{Kadar Protein}

Hasil sidik ragam menunjukkan bahwa perbandingan tepung ubi jalar ungu dan tepung kedelai berpengaruh nyata $(\mathrm{P}<0,05)$ terhadap kadar protein flakes. Tabel 1 menunjukkan kadar protein flakes berkisar antara $11,82 \%$ sampai dengan 19,68\%. Kadar protein tertinggi pada flakes diperoleh dari perlakuan P5 yaitu 19,68\%, sedangkan kadar protein terendah pada flakes diperoleh dari perlakuan P1 yaitu $11,82 \%$.

Peningkatan kadar protein terjadi seiring dengan meningkatnya penambahan tepung kedelai, hal ini disebabkan karena kadar protein tepung kedelai lebih tinggi dibandingkan kadar protein tepung ubi jalar ungu. Utami et al., (2018) menyatakan bahwa setiap $100 \mathrm{~g}$ tepung ubi jalar ungu mengandung $5,44 \%$ protein sedangkan tepung kedelai mengandung 30,03\% protein. Kedelai merupakan sumber protein nabati tertinggi dibandingkan dengan kacang-kacangan lainnya, serta susunan asam amino pada kedelai lebih lengkap dan seimbang (Koswara, 1992). Nilai kadar protein minimum yang sesuai menurut SNI : 01-4270-1996 adalah 5\% b/b (Anon, 2007), hal ini menunjukkan bahwa kadar protein dari semua perlakuan telah memenuhi syarat mutu flakes SNI.

\section{Kadar Serat Kasar}

Hasil sidik ragam menunjukkan bahwa perbandingan tepung ubi jalar ungu dan tepung kedelai berpengaruh nyata $(\mathrm{P}<0,05)$ terhadap kadar serat kasar flakes. Tabel 1 menunjukkan kadar serat kasar flakes berkisar antara 3,46\% sampai dengan 5,20\%. Kadar serat kasar tertinggi pada flakes diperoleh dari perlakuan P5 yaitu 5,20\%, sedangkan kadar serat kasar terendah pada flakes diperoleh dari perlakuan P1 yaitu 3,46\% yang berbeda tidak nyata dengan $\mathrm{P} 2$.

Peningkatan kadar serat kasar terjadi seiring dengan meningkatnya penambahan tepung kedelai, hal ini karena kandungan serat kasar pada tepung kedelai relatif lebih besar dibandingan dengan kadar serat kasar ubi jalar ungu. Heriyanto et al., (1999) menyatakan bahwa setiap $100 \mathrm{~g}$ tepung ubi jalar ungu mengandung 3,04\%, sedangkan menurut Aak (1990) menyatakan bahwa setiap $100 \mathrm{~g}$ kedelai mengandung 4,00\% serat kasar. 
Tabel 2. Nilai rata-rata total antosianin, aktivitas antioksidan dan daya serap air flakes fungsional

\begin{tabular}{cccc}
\hline Perlakuan & $\begin{array}{c}\text { Total Antosianin } \\
(\mathrm{mg} / 100 \mathrm{~g})\end{array}$ & $\begin{array}{c}\text { Aktivitas } \\
\text { Antioksidan }(\%)\end{array}$ & Daya Serap Air $(\%)$ \\
\hline P1 & $25,87 \pm 0,35^{\mathrm{a}}$ & $42,92 \pm 0,73^{\mathrm{a}}$ & $172,30 \pm 0,40^{\mathrm{a}}$ \\
P2 & $24,71 \pm 0,30^{\mathrm{b}}$ & $41,56 \pm 0,80^{\mathrm{b}}$ & $167,73 \pm 0,95^{\mathrm{b}}$ \\
P3 & $21,07 \pm 0,60^{\mathrm{c}}$ & $39,55 \pm 0,87^{\mathrm{c}}$ & $165,66 \pm 0,58^{\mathrm{c}}$ \\
P4 & $20,11 \pm 0,08^{\mathrm{d}}$ & $37,93 \pm 0,19^{\mathrm{d}}$ & $164,00 \pm 0,20^{\mathrm{d}}$ \\
P5 & $18,49 \pm 0,54^{\mathrm{e}}$ & $36,30 \pm 0,35^{\mathrm{e}}$ & $162,76 \pm 0,25^{\mathrm{e}}$ \\
\hline
\end{tabular}

Keterangan: Nilai rata - rata yang diikuti oleh huruf yang berbeda pada kolom yang sama menunjukkan perlakuan yang berbeda nyata $(\mathrm{P}<0,05)$.

\section{Total Antosianin}

Hasil sidik ragam menunjukkan bahwa perbandingan tepung ubi jalar ungu dan tepung kedelai berpengaruh nyata $(\mathrm{P}<0,05)$ terhadap total antosianin flakes. Tabel 2 menunjukkan total antosianin flakes berkisar antara $18,49 \mathrm{mg} / 100 \mathrm{~g}$ sampai dengan 25,87 $\mathrm{mg} / 100 \mathrm{~g}$. Total antosianin tertinggi pada flakes diperoleh dari perlakuan P1 yaitu 25,87 $\mathrm{mg} / 100 \mathrm{~g}$, sedangkan total antosianin terendah pada flakes diperoleh dari perlakuan P5 yaitu $18,49 \mathrm{mg} / 100 \mathrm{~g}$.

Total antosianin yang dihasilkan menunjukkan penurunan yang signifikan seiring dengan meningkatnya penggunaan tepung kedelai, hal ini di karenakan tepung kedelai tidak mengandung senyawa antosianin, adanya senyawa antosianin pada flakes disebabkan oleh sumbangan senyawa antosianin dari tepung ubi jalar ungu. Tepung ubi jalar ungu mengandung antosianin yang dapat berfungsi sebagai antioksidan dan sebagai pewarna alami. Kandungan antosianin dari ubi jalar ungu berkisar antara $110 \mathrm{mg} / 100$ g sampai $210 \mathrm{mg} / 100 \mathrm{~g}$ (Suprapta, 2004). Menurut Nollet (1996) Antosianin adalah pigmen yang larut dalam air, yang menyebabkan warna merah, violet, dan biru menurut $\mathrm{pH}$. Antosianin sebagai antioksidan bermanfaat sebagai pencegah reaksi oksidasi dari radikal bebas, secara umum radikal bebas timbul akibat terpaparnya tubuh dengan polusi lingkungan.

\section{Aktivitas Antioksidan}

Hasil sidik ragam menunjukkan bahwa perbandingan tepung ubi jalar ungu dan tepung kedelai berpengaruh nyata $(\mathrm{P}<0,05)$ terhadap aktivitas antioksidan flakes. Tabel 2 menunjukkan aktivitas antioksidan flakes berkisar antara $36,30 \%$ sampai dengan 42,92\%. Aktivitas antioksidan tertinggi pada flakes diperoleh dari perlakuan $\mathrm{P} 1$ yaitu 42,92\%, sedangkan aktivitas antioksidan terendah pada flakes diperoleh dari perlakuan P5 yaitu 36,30\%. 
Penurunan aktivitas antioksidan terjadi seiring dengan meningkatnya penggunaan tepung kedelai. Tepung kedelai memiliki senyawa isoflavon yang dapat bekerja sebagai antioksidan yang sangat sensitif terhadap proses pengolahan salah satunya adalah pemanasan, yang mana dapat mengubah struktur kimia dari isoflavon (Yulifianti et al., 2018). Selain itu adanya aktivitas antioksidan di sumbangkan oleh senyawa antosianin yang dimiliki oleh tepung ubi jalar ungu. Aktivitas antioksidan dari produk flakes sejenis berkisar antara 51,06\% - 65,24\% untuk flakes ubi jalar ungu-beras hitam (Angelina, 2017) dan $52,26 \%$ - 65,24\% untuk flakes ubi jalar ungu beras merah (Tejosaputro, 2017). Kelompok senyawa flavonoid seperti antosianin merupakan salah satu kelompok bahan alami pada tumbuhan yang berperan sebagai antioksidan (Pieta, 2000). Hasil pengujian aktivitas antioksidan ini berkolerasi positif dengan hasil pengujian total antosianin yang dilakukan. Berdasarkan penelitian Dwidjanarko (2008), aktivitas antioksidan tertinggi pada ubi jalar ungu adalah $61,24 \%$ $89,06 \%$.

\section{Daya Serap Air}

Hasil sidik ragam menunjukkan bahwa perbandingan tepung ubi jalar ungu dan tepung kedelai berpengaruh nyata $(\mathrm{P}<0,05)$ terhadap daya serap air flakes. Tabel 2 menunjukkan daya serap air flakes berkisar antara $162,767 \%$ sampai dengan $172,300 \%$. Daya serap air tertinggi pada flakes diperoleh dari perlakuan P1 yaitu 172,300\%, sedangkan daya serap air terendah pada flakes diperoleh dari perlakuan P5 yaitu 162,767\%.

Uji daya serap air dilakukan untuk mengetahui besar kemampuan flakes dalam menyerap air. Pada pengujian daya serap air diperoleh hasil bahwa semakin meningkat penggunaan tepung kedelai menyebabkan daya serap air semakin rendah, hal ini disebabkan karena kandungan pati pada tepung ubi jalar ungu cukup tinggi sehingga dapat meningkatkan penyerapan air. Widowati (2009) melaporkan bahwa kandungan pati pada ubi jalar ungu terdiri dari 30-40\% amilosa dan 60-70\% amilopektin. Peningkatan daya serap air disebabkan oleh adanya pati yang telah tergelatinisasi selama proses pengeringan. Gelatinisasi meningkatkan daya serap air karena terputusnya ikatan hidrogen antarmolekul pati sehingga air lebih mudah masuk ke dalam molekul pati (Santosa et al., 1998). Dinding sel akan menyerap air dan melunak jika bahan kering direndam dalam air. Dengan adanya elastisitas, dinding sel akan kembali ke bentuk semula. Setiap perlakuan yang mempengaruhi elastisitas dinding sel akan mempengaruhi volume rehidrasi dari jaringan, elastisitas dinding sel dan daya serap merupakan hal penting dalam rehidrasi yang dipengaruhi oleh panas (Umar et al., 2018). 


\section{Sifat Sensoris}

Evaluasi sensoris flakes fungsional dilakukan dengan uji hedonik dan skoring. Uji hedonik dilakukan terhadap aroma, warna, rasa, tekstur dan penerimaan keseluruhan. Uji skoring dilakukan terhadap warna dan tekstur.

Nilai rata-rata uji skoring dan uji hedonik terhadap warna dan uji hedonik aroma flakes fungsional dapat dilihat pada Tabel 3. Nilai rata-rata uji skoring dan uji hedonik terhadap tekstur dan uji hedonik rasa serta penerimaan keseluruhan flakes fungsional dapat dilihat pada Tabel 4.

Tabel 3. Nilai rata-rata uji skoring dan hedonik warna serta hedonik aroma flakes fungsional

\begin{tabular}{cccc}
\hline Perlakuan & Skoring Warna & Hedonik Warna & Hedonik Aroma \\
\hline P1 & $2,85 \pm 0,36^{\mathrm{a}}$ & $4,05 \pm 0,75^{\mathrm{a}}$ & $3,80 \pm 0,76^{\mathrm{a}}$ \\
P2 & $2,80 \pm 0,41^{\mathrm{a}}$ & $3,95 \pm 0,75^{\mathrm{a}}$ & $3,70 \pm 0,73^{\mathrm{a}}$ \\
P3 & $2,60 \pm 0,50^{\mathrm{ab}}$ & $3,70 \pm 0,73^{\mathrm{a}}$ & $3,95 \pm 0,68^{\mathrm{a}}$ \\
P4 & $2,35 \pm 0,58^{\mathrm{b}}$ & $3,55 \pm 0,75^{\mathrm{a}}$ & $3,90 \pm 0,64^{\mathrm{a}}$ \\
P5 & $1,70 \pm 0,65^{\mathrm{c}}$ & $3,05 \pm 0,94^{\mathrm{b}}$ & $4,15 \pm 0,74^{\mathrm{a}}$ \\
\hline
\end{tabular}

Keterangan : Nilai rata - rata yang diikuti oleh huruf yang berbeda pada kolom yang sama menunjukkan perlakuan yang berbeda nyata $(\mathrm{P}<0,05)$.

Kriteria skoring warna: 1 (ungu); 2 (agak ungu); 3 (tidak ungu)

Kriteria skoring tekstur: 1 (renyah); 2 (agak renyah); 3 (tidak renyah)

Kriteria hedonik: 1 (sangat suka); 2 (suka); 3 (biasa); 4 (tidak suka); 5 (sangat tidak suka)

\section{Warna}

Hasil sidik ragam menunjukkan bahwa perbandingan tepung ubi jalar ungu dan tepung kedelai berpengaruh nyata $(\mathrm{P}<0,05)$ terhadap warna flakes dengan uji skoring. Tabel 3 menunjukkan bahwa nilai rata-rata skor terendah terhadap warna flakes diperoleh pada perlakuan P5 yaitu 1,70 dengan kriteria agak ungu sedangkan nilai tertinggi diperoleh pada perlakuan P1 yaitu 2,85 dengan kriteria ungu yang berbeda tidak nyata dengan perlakuan P2 dan P3. Hasil sidik ragam menunjukkan bahwa perbandingan tepung ubi jalar ungu dan tepung kedelai berpengaruh nyata $(\mathrm{P}<0,05)$ terhadap warna flakes dengan uji hedonik. Tabel 3 menunjukkan bahwa nilai rata-rata tingkat kesukaan terendah tehadap warna flakes diperoleh pada perlakuan P5 yaitu 3,05 (biasa) sedangkan nilai tertinggi diperoleh pada perlakuan P1 yaitu 4,05 (suka) yang berbeda tidak nyata dengan P2, P3 dan P4.

Panelis menyatakan bahwa semakin tinggi rasio tepung kedelai maka warna flakes menjadi tidak ungu, warna ungu diperoleh dari tepung ubi jalar ungu yang memiliki pigmen warna ungu, sedangkan warna putih kekuningan diperoleh dari tepung kedelai, 
sehingga apabila rasio tepung kedelai semakin meningkat maka warna flakes yang dihasilkan akan semakin tidak ungu. Warna ungu yang terdapat pada flakes cenderung meningkatkan tingkat kesukaan panelis terhadap flakes. Menurut Winarno (2004) warna merupakan komponen yang sangat penting untuk menentukan kualitas atau penerimaan suatu bahan pangan. Suatu bahan pangan meskipun dinilai enak dan teksturnya sangat baik, tetapi memiliki warna yang tidak menarik atau memberi kesan telah menyimpang dari warna yang seharusnya maka bahan tersebut tidak akan dikonsumsi. Penentuan mutu suatu bahan pangan pada umumnya tergantung pada warna karena warna tampil terlebih dahulu.

\section{Aroma}

Hasil sidik ragam menunjukkan bahwa perbandingan tepung ubi jalar ungu dan tepung kedelai berpengaruh tidak nyata $(\mathrm{P}>0,05)$ terhadap aroma flakes dengan uji hedonik. Tabel 3 menunjukkan bahwa nilai rata-rata tingkat kesukaan panelis berkisar antara 3,70 sampai dengan 4,15 dengan kriteria suka. Penilaian tingkat kesukaan oleh panelis tidak berbeda nyata pada tiap perlakuan.

Tabel 4. Nilai rata-rata uji skoring dan hedonik tekstur, hedonik rasa serta penerimaan keseluruhan flakes fungsional

\begin{tabular}{ccccc}
\hline Perlakuan & Skoring Tekstur & Hedonik Tekstur & Hedonik Rasa & $\begin{array}{c}\text { Penerimaan } \\
\text { keseluruhan }\end{array}$ \\
\hline P1 & $2,50 \pm 0,74^{\mathrm{a}}$ & $3,50 \pm 0,82^{\mathrm{b}}$ & $3,70 \pm 1,03^{\mathrm{a}}$ & $3,65 \pm 0,81^{\mathrm{a}}$ \\
P2 & $2,55 \pm 0,60^{\mathrm{a}}$ & $3,80 \pm 0,89^{\mathrm{ab}}$ & $3,85 \pm 0,74^{\mathrm{a}}$ & $3,80 \pm 0,83^{\mathrm{a}}$ \\
P3 & $2,60 \pm 0,59^{\mathrm{a}}$ & $4,35 \pm 0,81^{\mathrm{a}}$ & $4,00 \pm 0,97^{\mathrm{a}}$ & $4,15 \pm 0,81^{\mathrm{a}}$ \\
P4 & $2,80 \pm 0,41^{\mathrm{a}}$ & $4,00 \pm 0,91^{\mathrm{ab}}$ & $3,90 \pm 0,96^{\mathrm{a}}$ & $3,90 \pm 0,55^{\mathrm{a}}$ \\
P5 & $2,70 \pm 0,47^{\mathrm{a}}$ & $4,30 \pm 0,86^{\mathrm{a}}$ & $3,60 \pm 0,75^{\mathrm{a}}$ & $4,00 \pm 0,85^{\mathrm{a}}$ \\
\hline
\end{tabular}

Keterangan : Nilai rata - rata yang diikuti oleh huruf yang berbeda pada kolom yang sama menunjukkan perlakuan yang berbeda nyata $(\mathrm{P}<0,05)$.

Kriteria skoring warna: 1 (ungu); 2 (agak ungu); 3 (tidak ungu)

Kriteria skoring tekstur: 1 (renyah); 2 (agak renyah); 3 (tidak renyah)

Kriteria hedonik: 1 (sangat suka); 2 (suka); 3 (biasa); 4 (tidak suka); 5 (sangat tidak suka)

\section{Tekstur}

Hasil sidik ragam menunjukkan bahwa perbandingan tepung ubi jalar ungu dan tepung kedelai berpengaruh tidak nyata $(\mathrm{P}>0,05)$ terhadap tekstur flakes dengan uji skoring. Tabel 4 menunjukkan bahwa nilai rata-rata skor panelis terhadap tekstur flakes berkisar antara 2,50 sampai dengan 2,80 dengan kriteria renyah. Hasil sidik ragam menunjukkan bahwa perbandingan tepung ubi jalar ungu dan tepung kedelai berpengaruh nyata $(\mathrm{P}<0,05)$ terhadap tekstur flakes dengan 
uji hedonik. Tabel 4 menunjukkan bahwa nilai rata-rata tingkat kesukaan terendah terhadap tekstur flakes diperoleh pada perlakuan P1 3,50 (suka) sedangkan nilai tertinggi diperoleh pada perlakuan P3 4,35 (suka) yang berbeda tidak nyata dengan P5. Rata-rata panelis menyukai hampir semua perlakuan karena memberikan tekstur flakes yang renyah. Menurut (Winarno, 1995) air merupakan komponen penting dalam bahan pangan karena air mampu mempengaruhi penampakan, tekstur dan cita rasa makanan. Pada seluruh perlakuan memiliki tekstur yang renyah karena memiliki kadar air yang rendah.

\section{Rasa}

Hasil sidik ragam menunjukkan bahwa perbandingan tepung ubi jalar ungu dan tepung kedelai berpengaruh tidak nyata $(\mathrm{P}>0,05)$ terhadap rasa flakes dengan uji hedonik. Tabel 4 menunjukkan bahwa nilai rata-rata tingkat kesukaan panelis yaitu 3,60 sampai dengan 4,00 dengan kriteria suka. Penilaian tingkat kesukaan oleh panelis tidak berbeda nyata pada tiap perlakuan.

\section{Penerimaan Keseluruhan}

Hasil sidik ragam menunjukkan bahwa perbandingan tepung ubi jalar ungu dan tepung kedelai berpengaruh tidak nyata $(\mathrm{P}>0,05)$ terhadap penerimaan keseluruhan flakes dengan uji hedonik. Tabel 4 menunjukkan bahwa nilai rata-rata uji hedonik terhadap penerimaan keseluruhan flakes berkisar antara 3,65 sampai dengan 4,15 dengan kriteria suka. Panelis rata-rata menyukai seluruh perlakuan dari flakes. Penerimaan keseluruhan flakes dipengaruhi oleh beberapa faktor seperti aroma, warna, rasa dan tekstur.

\section{KESIMPULAN DAN SARAN}

\section{Kesimpulan}

Perbandingan $70 \%$ tepung ubi jalar ungu dan 30\% tepung kedelai menghasilkan karakteristik flakes terbaik dengan kriteria kadar air 3,05\%, kadar abu 2,09\%, kadar protein $17,04 \%$, kadar serat kasar 3,76\%, total antosianin $21,07 \mathrm{mg} / 100 \mathrm{~g}$, aktivitas antioksidan $39,55 \%$ dan daya serap air $165,66 \%$, skoring warna ungu dan hedonik warna disukai, hedonik aroma disuka, skoring tekstur renyah dan hedonik tekstur disukai, hedonik rasa disukai, serta penerimaan keseluruhan disukai.

\section{Saran}

Perlu dilakukan penelitian lebih lanjut mengenai umur simpan pada produk flakes sehingga dapat diketahui berapa lama produk flakes dapat bertahan.

\section{DAFTAR PUSTAKA}

Aak. 1990. Kedele. Kanisius., Yogyakarta. Angelina, M. E. 2017. Pengaruh Perbedaan Proporsi Tepung Beras Hitam dan Tepung Ubi Jalar Ungu terhadap Sifat Kimia Flakes. Skripsi S-1. Tidak dipublikasikan. Fakultas Teknologi 
Pertanian, Universitas Katolik Widya Mandala, Surabaya.

Anonimous. 1981. Daftar Komposisi Bahan Makanan. Direktorat Gizi Departemen kesehatan RI., Jakarta.

Anonimous. 2007. Syarat Mutu Flakes (SNI 01-4270-1996). Badan Standarisasi Nasional., Jakarta.

Cheng, G. W. dan P. J. Breen. 1991. Activity of phenylalanine ammonialyase (pal) and concentration of anthocyanins and phenolics in developing strawberry fruit. J. Ameer. Soc. Hort Sci. 116.

Dewi, S. K. 2008. Pembuatan Produk Nasi Instan Berbasis Fermented Cassava Flour Sebagai Bahan Pangan Alternatif. Skripsi S-1. Dipublikasikan. Fakultas Teknologi Pertanian, Institut Pertanian Bogor, Bogor.

Dwidjanarko, S. 2008. Efek pengolahan terhadap perubahan fisiko-kimia ubi jalar ungu dan kuning. http:// Simonbwidjanarko.files.wordpress.com. (20 Juni 2020).

Ekawati, I. G. A., N. M. I. H. Arihantana dan P. A. S. Wipradnyadewi. 2013. Pemanfaatan tepung ubi ungu termodifikasi sebagai pangan sehat. Laporan Penelitian Hibah Bersaing. Universitas Udayana, Denpasar.

Gomez, K. A. dan A. A. Gomez. 1995. Prosedur Statistik Untuk Penelitian Pertanian. UI Press., Jakarta.

Gupta, R. K. 1990. Processing of Fruit Vegetables and Other Food Processing (Process ood Industries). SBP of Consultant Engineers., New Delhi.

Heriyanto, N., Prasetiaswati dan S.S Antarlina. 1999. Kajian pemanfaatan tepung ubi sebagai bahan baku industri pangan. 20 (2) : 45-54.

Herlina E., dan F. Nuraeni. 2014. Pengembangan produk pangan fungsional berbasis ubi kayu (manihot esculata) dalam menunjang ketahanan pangan. 3 (2) : $142-148$.

Jusuf, M, Rahayuningsih, S. A dan Ginting, E. 2003. Ubi jalar ungu. Warta Penelitian dan Pengembangan Pertanian. 30 : 13-14.
Khan, R. A. 2012. Evaluation of flavonoids and diverse antioxidant activities of Sonchus arvensis. Chemistry Central Journal. $6: 126$.

Nollet, L. M. L. 1996. Handbook of Food Analysis : Physical Characterization and Nutrient Analysis. Marcell Dekker Inc., New York.

Nurali, E. J. N., M. B. Lelemboto, dan Y. Amu. 2010. Pemanfaatan ubi jalar (Ipomea batatas L.) sebagai bahan baku pembuatan flakes dengan substitusi tepung kedele (Glicyne max L. MERR). Teknologi Pertanian. 5 (2).

Pehulisa, A., P. Usman dan R. Evy. 2016. Pemanfaatan tepung ubi jalar ungu dan tepung kulit ari kacang kedelai dalam pembuatan flakes. Teknologi Pertanian. 3 (1).

Permana, R. A. dan P. W. D. Rukmi. 2015. Pengaruh proporsi jagung dan kacang merah serta subtitusi bekatul terhadap karakteristik fisik kimia flakes. Pangan dan Agroindustri. 3 (2):734-742.

Pieta, P. G. 2000. Flavonoid as antioxidant. J. matt prod. 63 : 1035 - 1043.

Santosa, B. A., S. Narta dan D. S. Damardjati. 1998. Pembuatan brondong dari berbagai beras. Agritech. 18 (1) :24 - 28.

Santoso, W. E. A. dan E. Teti. 2014. Jurnal review : kopigmentasi ubi jalar ungu (Ipomoea batatas var ayamurasaki) dengan kopigmen na-kaseinat dan protein whey serta stabilitasnya terhadap pemanasan. Pangan Dan Agroindustri. 2 : $121-127$.

Somaatmadja, S. 1993. Sumber Daya Nabati Asia Tenggara 1 Kacang-Kacangan. PT Gramedia Pustaka Utama., Jakarta.

Sudarmadji, S., B. Haryono dan Suhardi. 1997. Prosedur Analisis Untuk Bahan Makanan dan Pertanian. Liberty., Yogyakarta.

Suprapta, D.N. 2004. Kajian Aspek Pembibitan, Budi Daya dan Pemanfaatan Umbi-Umbian sebagai Sumber Pangan Alternatif. Laporan Hasil Penelitian. Kerja sama BAPEDA Provinsi Bali dengan Fakultas Pertanian UNUD. 
Tejosaputro, K., T. Indarto dan I. Radix. 2017. Pengaruh perbedaan proporsi tepung ubi jalar ungu dan tepung beras merah terhadap sifat flakes. Teknologi Pangan dan Gizi. 16 (2).

Utami, P. A. S., I. M. Sugitha dan N. M. I. H. Arihantana. 2018. Pengaruh perbandingan tepung ubi jalar ungu dan tepung kedelai terhadap karakteristik cookies. Jurnal Ilmu dan Teknologi Pangan. 7 (3).
Widowati, S. 2009. Tepung Aneka Umbi Sebuah Solusi Ketahanan Pangan. Balai Besar Penelitian dan Pengembangan Pascapanen Pertanian. Tabloid Sinar Tani., Jakarta.

Winarno, F. G. 2004. Hasil-hasil Simposium Penganekaragaman Pangan. Prakarsa Swasta dan Pemda., Jakarta.

Winarno, F.G. 1995. Enzim Pangan. Penerbit PT. Gedia Pustaka Utama., Jakarta.

Winarno, F.G. 2002. Kimia Pangan dan Gizi. PT. Gramedia Pustaka Utama., Jakarta. 